\title{
Pemodelan Kondisi Optimum Ekstraksi dan Identifikasi Senyawa Penyusun Minyak Atsiri Lada Hitam
}

\section{(Extraction Process Optimation Modelling and Identification Black Pepper Essential Oil)}

\author{
Shintawati ${ }^{1^{*}}$, Analianasari ${ }^{1}$, Zukryandry ${ }^{1}$ \\ 1 Jurusan Teknologi Pertanian, Politeknik Negeri Lampung Jl. Soekarno-Hatta No. 10 \\ Rajabasa, Bandar Lampung, 35144, Telp.:(0721) 703995, Fax.: (0721) 787309 \\ E-mail: shintawati@polinela.ac.id
}

\section{ARTICLE INFO}

Article history

Submitted: June 16, 2021

Accepted: October 9, 2021

Published: October 23, 2021

Keywords:

composition,

extraction,

GCMS,

response surface method

\begin{abstract}
Black pepper is a spice with a spicy taste and a distinctive aroma that has become known as the King of Spices. The distinctive aroma of black pepper comes from the volatile compounds that make up the essential oil of pepper. Black pepper essential oil has antimicrobial properties that can relieve respiratory infections and relieve muscle disorders. The acquisition of pepper essential oil from the distillation process is influenced by operating conditions. The aim of this study was to identify the composition of black pepper essential oil compounds using GCMS and to optimize the operating conditions (material size, solvent ratio, and distillation time). The method used to determine the optimum condition is using the Response Surface Method (RSM). The results showed that the highest yield of black pepper essential oil from this experiment is $5.14 \%$. The empirical model was also suitable for the experiment and the optimum conditions for producing the maximum pepper oil yield 5,81\%

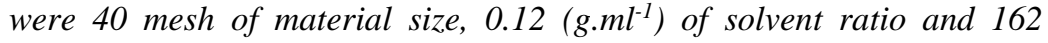
minutes of distillation time. GCMS test results showed that the main constituents of pepper essential oil are caryophyllene, ocimene, limonene, carene, and $\alpha$-pinene.
\end{abstract}

Copyright (C) 2021 Author(s). This work is licensed under a Creative Commons AttributionShareAlike 4.0 International License.

\section{PENDAHULUAN}

Biji lada hitam merupakan buah tanaman Piper nigrum dengan famili Piperaceae yang diperoleh dari pengeringan langsung tanpa melalui proses pengolahan. Lada digunakan sebagai bahan pangan rempah, memiliki manfaat bagi kesehatan antara lain meningkatkan kemampuan cerna terhadap makanan, pengobatan batuk, memperbaiki permasalahan pernafasan dan masalah otot jantung, diabetes, analgesik dan anemia (Alyaseen et al., 2018). Minyak atsiri lada merupakan produk hasil distilasi lada yang kaya akan senyawa volatil. Aplikasi minyak atsiri lada hitam banyak digunakan sebagai bahan pereda infeksi pernafasan dan meringankan nyeri otot. Permasalahan dalam pengembangan industri berbahan baku lada hitam adalah masih terbatasnya penelitian kondisi optimum ekstraksi minyak lada dan identifikasi senyawa yang terkandung dalam minyak lada.

Kondisi ekstraksi seperti suhu dan tekanan operasi, ukuran bahan baku, perbandingan jumlah bahan baku dan perlarut serta lamanya waktu distilasi akan mempengaruhi rendemen minyak atsiri 
hasil distilasi. Kondisi operasi proses ekstraksi dan lokasi tanam juga akan mempengaruhi komposisi senyawa yang ada di dalam produk minyak atsiri (Anggraini et al., 2018). Ekstraksi minyak atsiri lada hitam asal Vietnam menghasilkan rendemen tertinggi 2,14\% pada kondisi ukuran lada 160 mesh, rasio pelarut 0,048 g.ml ${ }^{-1}$ dan waktu distilasi 5,2 jam dengan kandungan senyawa terbesar 3-carene (29,21\%), limonene (20,94\%), caryophyllene (15,05\%), dan B-pinene (9,77\%) (Tran et al., 2019).

Komposisi terbesar dalam minyak atsiri lada hitam asal Madagaskar dan Brazil menurut Dosoky et al. (2019) adalah $\alpha$-pinene, sabinene, $\beta$-pinene, 3 -carene, limonene, dan $\beta$-caryophyllene. Kajian kondisi optimum ekstraksi serta komposisi senyawa penyusun minyak atsiri lada hitam asal Provinsi Lampung masih terbatas. Penelitian ini bertujuan untuk mempelajari proses ekstraksi minyak lada hitam asal Provinsi Lampung melalui optimasi kondisi operasi (perbandingan pelarut, waktu distilasi, dan ukuran partikel bahan baku) menggunakan response surface method (RSM) serta mengidentifikasi komposisi senyawa minyak atsiri lada hitam menggunakan gas cromatography and mass spectroscopy (GCMS). RSM merupakan suatu metode statistika untuk perancangan percobaan, optimasi proses, dan pemodelan matematika untuk memprediksi perolehan di akhir proses (Kusuma \& Mahfud, 2015). RSM meninjau 2 atau lebih variabel proses yang berinteraksi satu dengan yang lain secara simultan (Anuar et al., 2013).

\section{METODE PENELITIAN}

Lada hitam yang digunakan berasal dari petani lada di Kecamatan Kebun Tebu Kabupaten Lampung Barat Provinsi Lampung. Penelitian dilaksanakan bulan Juni hingga Oktober 2020 di Laboratorium Balai Pengujian dan Sertifikasi Mutu Barang Dinas Perindustrian dan Perdagangan Provinsi Lampung. Bahan pembantu lainnya antara lain aquadest dan batu didih. Alat yang digunakan adalah seperangkat alat hidrodistilasi Clavenger, termometer, piknometer, ayakan 10, 20, 30 dan 40 mesh, oven dan neraca analitik dan instrumen GCMS dengan detektor FID. Metode pengujian kadar air lada hitam menggunakan metode gravimetri sesuai SNI 01 2891-1992 tentang Cara Uji Makanan dan Minuman.

Penelitian ini melibatkan 3 variabel bebas yaitu perbandingan bahan baku terhadap pelarut/ $\mathrm{X}_{1}$ $\left(0,07\right.$ g.ml ${ }^{-1}, 0,12$ g.ml ${ }^{-1}$, dan 0,17 g.ml $\left.l^{-1}\right)$, ukuran sampel/ $\mathrm{X}_{2}(-10+20$ mesh, $-20+30$ mesh, dan $-30+40$ mesh), dan waktu distilasi $/ \mathrm{X}_{3}$ (60 menit, 135 menit, dan 210 menit). Minyak atsiri lada hitam dihitung perolehannya menggunakan rumus berikut (Kusuma \& Mahfud, 2015):

$$
y=\frac{v}{w} x 100 \%
$$

Dimana y adalah rendemen minyak atsiri lada hitam (\%), v adalah berat minyak atsiri lada hitam yang terbentuk (gram), dan w adalah berat lada hitam bubuk (gram). Perolehan minyak atsiri lada hitam merupakan variabel tidak bebas (respons) pada penelitian ini. Rancangan penelitian ini menggunakan RSM Box-Behnken dan diperoleh 15 perlakuan sebagaimana Tabel 1. 
Tabel 1. Rancangan penelitian menggunakan metode RSM Box-Behnken

\begin{tabular}{cccc}
\hline \multirow{2}{*}{ Perlakuan } & \multicolumn{3}{c}{ Variabel bebas } \\
\cline { 2 - 4 } & $\mathrm{X}_{1}$ & $\mathrm{X}_{2}$ & $\mathrm{X}_{3}$ \\
\hline 1 & 0,07 & $-10+20$ & 135 \\
3 & 0,17 & $-10+20$ & 135 \\
4 & 0,07 & $-30+40$ & 135 \\
5 & 0,17 & $-30+40$ & 135 \\
6 & 0,07 & $-20+30$ & 60 \\
7 & 0,17 & $-20+30$ & 60 \\
8 & 0,07 & $-20+30$ & 210 \\
9 & 0,17 & $-20+30$ & 210 \\
10 & 0,12 & $-10+20$ & 60 \\
11 & 0,12 & $-30+40$ & 60 \\
12 & 0,12 & $-10+20$ & 210 \\
13 & 0,12 & $-30+40$ & 210 \\
14 & 0,12 & $-20+30$ & 135 \\
15 & 0,12 & $-20+30$ & 135 \\
\hline
\end{tabular}

Keterangan: $\mathrm{X}_{1}=$ perbandingan bahan baku terhadap pelarut $\left(\mathrm{g} \cdot \mathrm{ml}^{-1}\right), \mathrm{X}_{2}=$ ukuran sampel bahan baku (mesh), dan $\mathrm{X}_{3}=$ waktu distilasi (menit).

\section{Pelaksanaan Penelitian}

\section{Persiapan bahan baku}

Penyeragaman kadar air biji lada hitam dilakukan dengan menjemur biji lada hitam di bawah sinar matahari selama 2 hari, hingga kadar air mencapai $12 \%$.

\section{Ekstraksi minyak atsiri lada hitam}

Lada hitam yang telah dikeringkan digiling lalu diayak dengan ukuran yang telah ditentukan (-10+20 mesh, $-20+30$ mesh dan -30+40 mesh). Bubuk lada yang telah diayak ditimbang sebanyak 35 gram, dimasukkan ke dalam distilator, ditambahkan pelarut dan didistilasi menggunakan metode hidrodistilasi selama waktu tertentu sesuai dengan rancangan penelitian pada Tabel 1. Minyak atsiri lada hitam yang terbentuk ditampung dalam oil trap dan berdasarkan berat jenis minyak atsiri lada yang lebih rendah dari air maka minyak atsiri berada pada lapisan atas yang terpisah dari air yang berada dilapisan bawah. Minyak atsiri dipisahkan dari air dengan membuka kran yang ada pada oil trap.

\section{Identifikasi komposisi minyak atsiri lada hitam}

Minyak atsiri lada hitam yang diperoleh dari ekstraksi disimpan dalam botol dan diberi natrium sulfat anhidrat, ditutupi dengan aluminium foil lalu disimpan pada suhu $4^{\circ} \mathrm{C}$ untuk kemudian diidentifikasi komposisinya menggunakan GCMS (Dosoky et al., 2019). Pengujian GCMS dilaksanakan di Laboratorium Balai Pengujian Mutu Barang Kementerian Perdagangan, Jakarta.

Pemodelan matematis untuk memperkirakan hasil percobaan didasarkan pada hubungan antar variabel bebas yang dinyatakan dalam persamaan polinomial kuadratik dengan bentuk umum sebagai berikut:

$$
Y=\beta o+\sum_{i=1}^{3} \beta_{i} X_{i}+\sum_{i=1}^{3} \beta_{i i} X_{i}^{2}+\sum_{i<j}^{3} \beta_{i j} X_{i} X_{j}
$$


Dimana $\beta_{\mathrm{o}}, \beta_{\mathrm{i}}, \beta_{\mathrm{ii}}, \beta_{\mathrm{ij}}$ merupakan koefisien regresi, Y merupakan variabel tidak bebas yang diperkirakan, dan $\mathrm{X}$ adalah variabel bebas. Persamaan model matematika, grafik 3 dimensi yang memprediksi interaksi antar variabel serta kondisi optimum ekstraksi ditentukan menggunaan software Minitab 19 (Pawignya et al., 2019).

\section{HASIL DAN PEMBAHASAN}

\section{Sifat Fisik dan Kimia Minyak Atsiri Lada Hitam}

Minyak atsiri lada hitam dari proses hidrodistilasi secara fisik berwarna bening dan memiliki wangi yang khas. Hasil uji GCMS (Gambar 1) terhadap minyak atsiri hasil perlakuan nomor 13 yaitu perlakuan yang memberikan rendemen tertinggi, menunjukkan 5 komponen kimia terbesar dalam minyak atsiri lada hitam adalah caryopyllene $(30,85 \%)$, ocimene $(17,74 \%)$, limonene $(13,81 \%), 3$ carene $(9,62 \%)$, dan $\alpha$-pinene $(4,48 \%)$. Jenis senyawa penyusun minyak atsiri lada hitam dari Kabupaten Lampung Barat memiliki kemiripan dengan senyawa penyusun minyak atsiri lada hitam dari Kalimantan Barat, yaitu trans-caryophellene (23,77\%), limonene (18,20\%), delta-3-carene (13,51\%), 2- $\beta$-pinene (9,54\%), dan sabinene (6,62\%) (Anggraini et al., 2018). Minyak atsiri lada hitam Lampung mengandung ocimene yang berfungsi sebagai antibakteri seperti Staphylococcus aureus, Salmonella enterica, dan Helicobacter pylori (Mahdian et al., 2017). Faktor-faktor yang mempengaruhi komposisi minyak atsiri antara lain teknik pengolahan tanah, curah hujan tahunan, tingkat pemupukan, waktu panen, pengeringan dan teknologi ekstraksi yang digunakan (Andras et al., 2018). Caryophyllene bertindak sebagai analgesik, antiinflamasi (Klauke et al., 2014), antikanker, analgesik (Fidyt et al., 2016), bahan kosmetik, antijamur, dan melemaskan otot akibat aktivitas fisik (Rmili et al., 2014). Limonene dan $\alpha$-pinene yang terkandung dalam minyak atsiri lada hitam merupakan senyawa yang memberikan aroma pada minyak atsiri lada (Lee et al., 2020) dan juga sebagai anti herpesvirus (Astani \& Schnitzler, 2014).

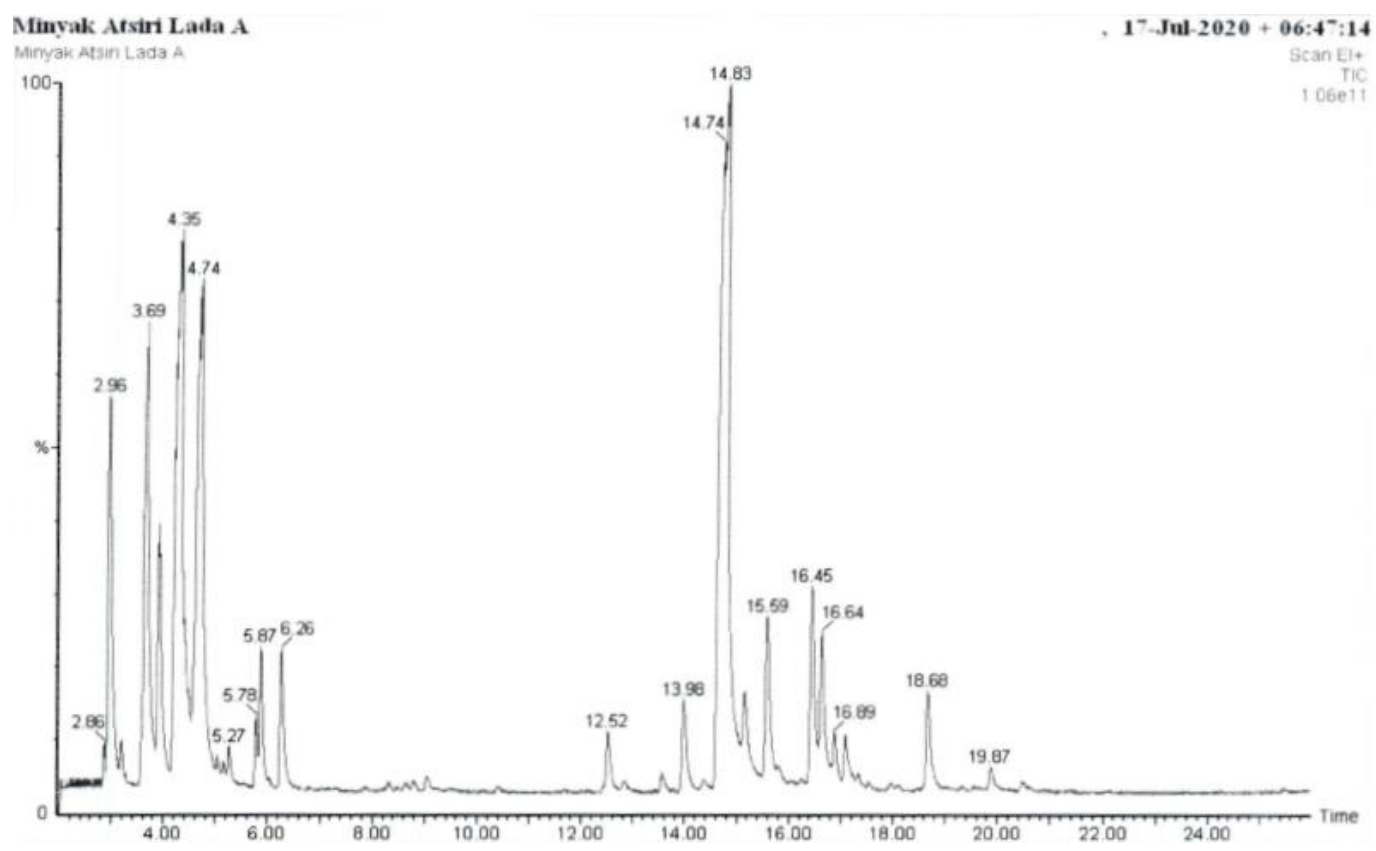

Gambar 1. Hasil uji GCMS minyak atsiri lada hitam Kecamatan Kebun Tebu Kabupaten Lampung Barat 


\section{Optimasi Kondisi Ekstraksi Minyak Atsiri Lada Hitam}

Rendemen minyak atsiri lada hitam dari hasil eksperimen ditampilkan pada Tabel 2.

Tabel 2. Rendemen minyak atsiri lada pada berbagai perlakuan

\begin{tabular}{ccc}
\hline Perlakuan & $\begin{array}{c}\text { Rendemen minyak atsiri lada dari } \\
\text { eksperimen }(\% \text { w/w })\end{array}$ & $\begin{array}{c}\text { Prediksi rendemen minyak atsiri } \\
\text { lada dari model }(\% \mathrm{w} / \mathrm{w})\end{array}$ \\
\hline 1 & 2,14 & 2,64 \\
2 & 2,57 & 2,92 \\
3 & 4,29 & 3,92 \\
4 & 4,29 & 3,79 \\
5 & 2,00 & 2,07 \\
6 & 1,86 & 2,07 \\
7 & 3,43 & 3,21 \\
8 & 3,43 & 3,36 \\
9 & 3,86 & 3,29 \\
10 & 4,43 & 4,71 \\
11 & 5,12 & 4,86 \\
12 & 5,00 & 5,57 \\
13 & 5,14 & 5,14 \\
14 & 5,14 & 5,14 \\
15 & 5,14 & 5,14 \\
\hline
\end{tabular}

Berdasarkan Tabel 2, dari hasil eksperimen diperoleh rendemen minyak atsiri lada hitam tertinggi yaitu 5,14\% diperoleh pada kondisi ukuran bahan $-20+30$ mesh, rasio sampel terhadap pelarut $0,12 \mathrm{~g} . \mathrm{ml}^{-1}$ dan waktu destilasi 135 menit. Minyak atsiri merupakan campuran senyawa mudah menguap, ukuran bahan baku yang terlalu kecil $-30+40$ mesh memungkinkan terjadinya kehilangan atau penguapan senyawa volatil tersebut selama proses penggilingan (Alam et.al, 2018). Ukuran bahan yang lebih besar $-10+20$ mesh berkorelasi dengan luas permukaan bahan yang sempit, sehingga kemudahan difusi minyak atsiri dari dalam bahan ke permukaan lebih lambat. Rasio pelarut berhubungan dengan densitas bahan dalam labu destilasi. Kepadatan bahan yang tinggi mengakibatkan lambatnya penguapan minyak atsiri yang berada di permukaan bahan akibat terhambatnya ruang gerak pelarut untuk membawa senyawa volatil. Perbandingan jumlah padatan terhadap pelarut merupakan faktor yang penting dalam proses hidrodistilasi (Rmili et al., 2014). Rasio jumlah padatan terhadap pelarut pada penelitian ini, $0,12{\mathrm{~g} . \mathrm{ml}^{-1}}^{-1}$ lebih tinggi dari penelitian Rmili et al. (2014) yaitu 0,0625 g. $\mathrm{ml}^{-1}$. Rasio jumlah padatan terhadap pelarut berkaitan dengan perancangan alat destilator, semakin tinggi rasio maka semakin sedikit volume pelarut yang digunakan maka kapasitas alat yang dibutuhkan akan semakin kecil. Pengaruh ukuran partikel bahan baku dan waktu distilasi berkaitan dengan intensitas kontak antara senyawa volatil dengan pelarut, semakin lama waktu kontak semakin besar transfer masa senyawa volatil melalui difusi dari bahan padat ke fasa uap. Namun, waktu distilasi yang panjang membutuhkan energi yang besar, yang merupakan salah satu biaya terbesar dalam industri minyak atsiri.

RSM merupakan metode statistika dalam mengolah satu kelompok data dari suatu eksperimen guna mengoptimasi dan menentukan koefisien model matematika (Pawignya et al., 2019). Analisis data menggunakan RSM menghasilkan model matematika sebagaimana Tabel 3. 
Tabel 3. Hasil analisis respons ekstraksi minyak atsiri lada hitam

\begin{tabular}{ccc}
\hline Model matematika & $\begin{array}{c}\text { Koefisien } \\
\text { determinasi }\end{array}$ & Nilai P \\
\hline $\mathrm{Y}=$ & 0,9204 & 0,027 \\
$+0,00054 \mathrm{X}_{2}^{2}-0,000105 \mathrm{X}_{3}^{2}-0,225 \mathrm{X}_{1} \mathrm{X}_{2}+0,0100 \mathrm{X}_{1} *$ & & \\
$\mathrm{X}_{3}-0,000238 \mathrm{X}_{2} * \mathrm{X}_{3}$ & & \\
\hline
\end{tabular}

Dimana $\mathrm{Y}$ adalah rendemen minyak atsiri lada hitam $(\% \mathrm{w} / \mathrm{w}), \mathrm{X}_{1}$ adalah rasio pelarut $\left(\mathrm{g} \cdot \mathrm{ml}^{-1}\right)$, $\mathrm{X}_{2}$ adalah ukuran sampel (mesh), dan $\mathrm{X}_{3}$ adalah waktu destilasi (menit). Nilai koefisien determinasi mencapai 0,9204 artinya $92,04 \%$ dari total data sesuai dengan hasil rendemen yang diprediksi oleh model dan hanya 7,96\% data yang salah (Pawignya et al., 2019). Rendemen minyak atsiri hasil prediksi dari model matematika disajikan pada Tabel 2. Dari hasil uji ANOVA diperoleh nilai P $<0,05$ yaitu 0,027 , hal ini menunjukkan bahwa model matematika bisa diterima pada selang kepercayaan $97,3 \%$.

Tabel 4. Pengaruh koefisien korelasi terhadap model matematika

\begin{tabular}{cccccc}
\hline Sumber & Derajat bebas & Jumlah kuadrat & Rata-rata kuadrat & Nilai F & Nilai P \\
\hline $\mathrm{X}_{1}$ & 1 & 0,0102 & 0,0102 & 0,03 & 0,868 \\
$\mathrm{X}_{2}$ & 1 & 2,2959 & 2,2959 & 6,86 & 0,047 \\
$\mathrm{X}_{3}$ & 1 & 2,9490 & 2,9490 & 8,81 & 0,031 \\
$\mathrm{X}_{1}{ }^{2}$ & 1 & 12,9808 & 12,9808 & 38,78 & 0,002 \\
$\mathrm{X}_{2}{ }^{2}$ & 1 & 0,0106 & 0,0106 & 0,03 & 0,866 \\
$\mathrm{X}_{3}{ }^{2}$ & 1 & 1,2822 & 1,2822 & 3,83 & 0,108 \\
$\mathrm{X}_{1} \mathrm{X}_{2}$ & 1 & 0,0459 & 0,0459 & 0,14 & 0,726 \\
$\mathrm{X}_{1} \mathrm{X}_{3}$ & 1 & 0,0051 & 0,0051 & 0,02 & 0,907 \\
$\mathrm{X}_{2} \mathrm{X}_{3}$ & 1 & 0,1276 & 0,1276 & 0,38 & 0,564 \\
\hline
\end{tabular}

Nilai P-Value pada Tabel 4 menunjukkan signifikansi koefisien regresi terhadap model. Variabel $\mathrm{X}_{2}$, ukuran bahan dan $\mathrm{X}_{3}$, waktu distilasi memiliki P-Value $<0,05$ menunjukkan koefisien kedua variabel bebas pada model memiliki pengaruh signifikan terhadap rendemen minyak atsiri. Nilai P-value dari interaksi antar variabel bebas lebih besar dari 0,05 yang menunjukkan interaksi antar variabel tidak berpengaruh terhadap rendemen minyak atsiri dan hal yang sama untuk kuadratik variabel $\mathrm{X}_{2}$ dan $\mathrm{X}_{3}$.

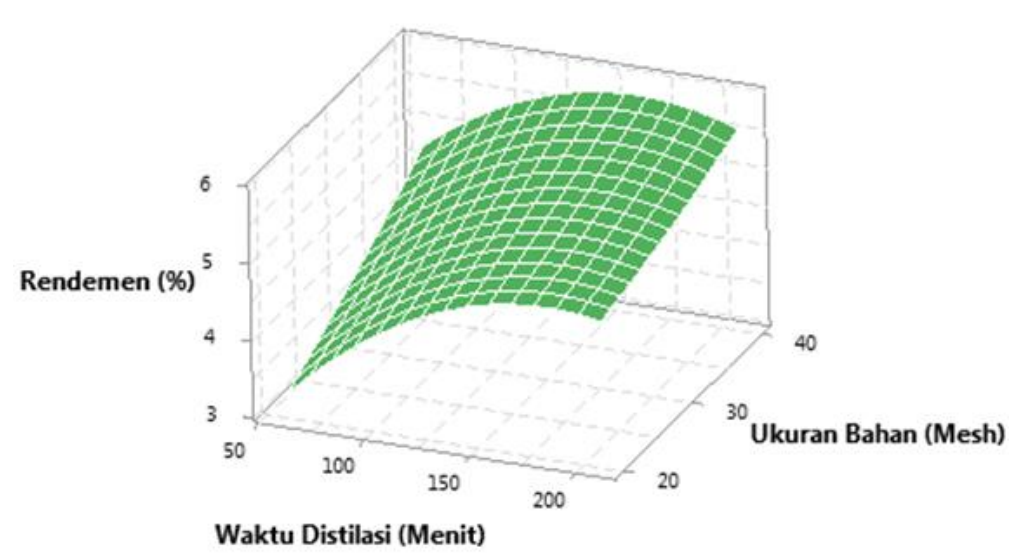

Gambar 2. Pengaruh waktu distilasi dan ukuran bahan terhadap rendemen minyak atsiri 
Pengaruh ukuran bahan dan waktu distilasi terhadap rendemen diperlihatkan pada Gambar 2. Gambar 2 memperlihatkan rendemen minyak atsiri akan meningkat dengan bertambahnya waktu distilasi dan bertambahnya ukuran mesh bahan baku. Rendemen cenderung konstan untuk waktu distilasi lebih dari 162 menit. Hal ini menunjukkan keseluruhan minyak atsiri lada terekstraksi setelah 162 menit.

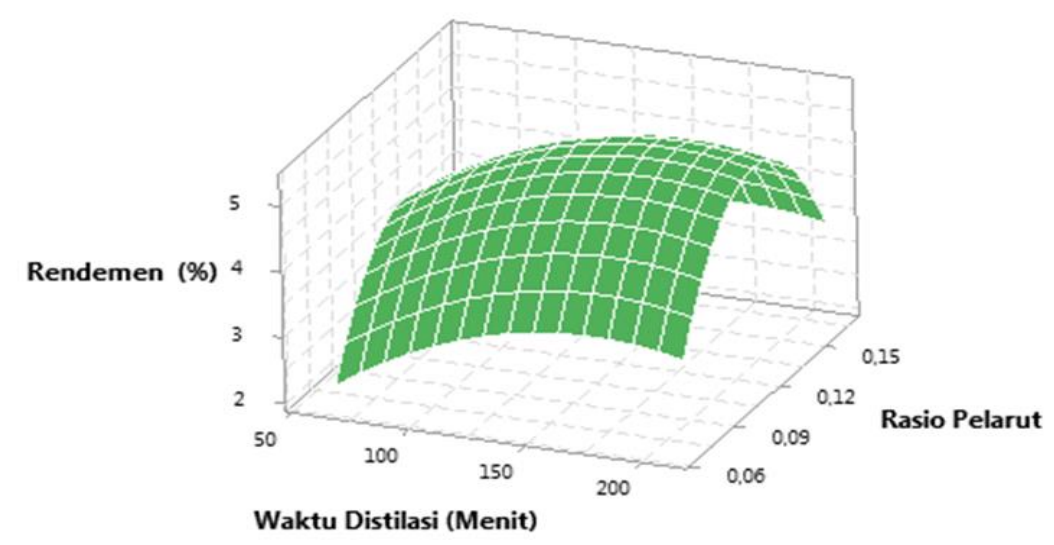

Gambar 3. Pengaruh waktu distilasi dan rasio pelarut terhadap rendemen minyak atsiri

Gambar 3 memperlihatkan rendemen minyak atsiri meningkat dengan bertambahnya waktu distilasi dan rasio pelarut. Rendemen mengalami penurunan pada rasio pelarut lebih dari $0,12 \mathrm{~g} \cdot \mathrm{ml}^{-1}$ dan waktu distilasi lebih dari 162 menit. Gambar 4 memperlihatkan peningkatan rasio pelarut dan ukuran bahan akan meningkatkan rendemen minyak atsiri. Rendemen akan mengalami penurunan pada rasio pelarut lebih dari $0,12 \mathrm{~g} \cdot \mathrm{ml}^{-1}$. Peningkatan ukuran mesh bahan akan memperluas permukaan bahan sehingga kontak antara pelarut dengan bahan akan meningkat dan senyawa volatil lebih mudah teruapkan (Rmili et al., 2014).

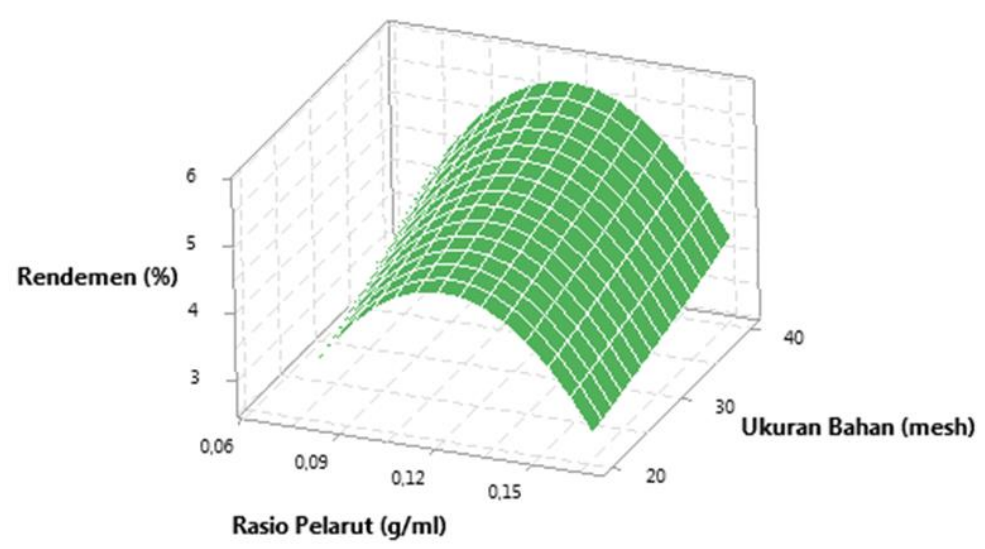

Gambar 4. Pengaruh rasio pelarut dan ukuran bahan terhadap rendemen minyak atsiri

Berdasarkan Gambar 5, kondisi operasi optimum ekstrasi minyak lada diperoleh pada kondisi rasio pelarut 0,12 g.ml-1 , ukuran bahan 40 mesh dan waktu distilasi 162 menit dengan rendemen maksimum $5,81 \%$. 


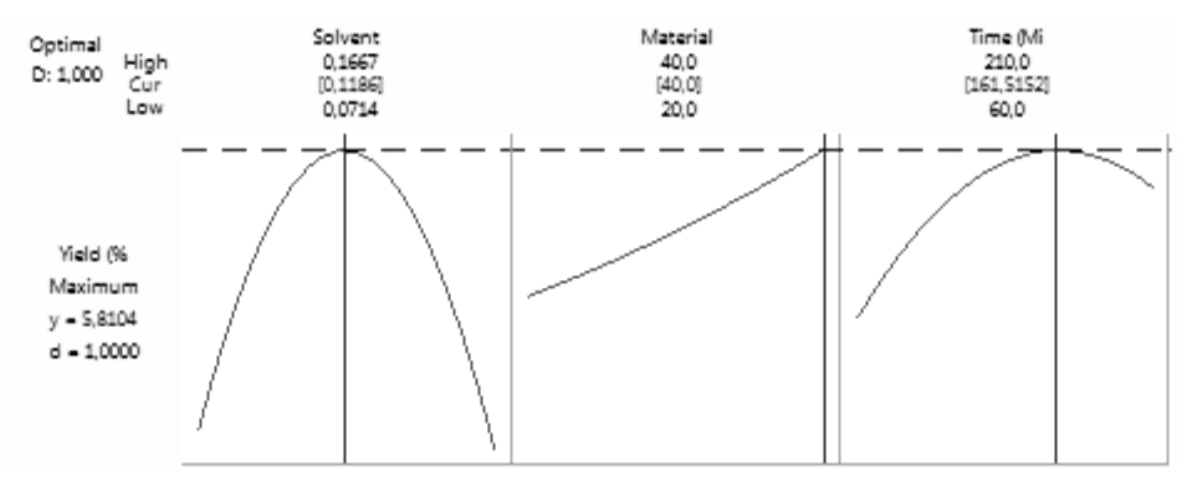

Gambar 5. Kondisi optimum ekstraksi yang menghasilkan rendemen tertinggi

\section{KESIMPULAN}

Rendemen minyak lada tertinggi dari hasil penelitian ini adalah 5,14\% dan melalui pemodelan diperoleh rendemen tertinggi sebesar 5,81\% yang dicapai pada kondisi optimum yaitu ukuran bahan 40 mesh, rasio pelarut $0,12\left(\mathrm{~g} \cdot \mathrm{ml}^{-1}\right)$ dan waktu distilasi 162 menit. Senyawa utama penyusun minyak atsiri lada asal Provinsi Lampung adalah caryopyllene, ocimene, dan limonene.

\section{UCAPAN TERIMA KASIH}

Terima kasih disampaikan kepada Unit Penelitian dan Pengabdian Masyarakat Politeknik Negeri Lampung yang telah mendanai penelitian ini melalui dana DIPA Politeknik Negeri Lampung Nomor: 193.27/PL.15.8/PT/2020 tanggal 5 Juni 2020.

\section{DAFTAR PUSTAKA}

Alyaseen, F. F., Hassan, B. A., \& Abdulhussein, H. S. (2018). Extraction, isolation and chemical identification of piperine alkaloid from black pepper seeds and its antibacterialactivity. Plant Archives, 18(2), 2171-2176.

Alam, P. N., Husin, H., Asnawi, T. M., \& Adisalamun. (2018). Extraction of citral oil from lemongrass (Cymbopogon Citratus) by steam-water distillation technique. IOP Conf. Ser.: Mater. Sci. Eng. 345 012022. https:// doi:10.1088/1757-899X/345/1/012022

Anggraini, R., Jayuska, A., \& Alimuddin, A. H. (2018). Isolasi dan karakterisasi minyak atsiri lada hitam (Piper nigrum L.) asal sajingan kalimantan barat. Jurnal Kimia Khatulistiwa, 7(4), 124133.

Anuar, N., Mohd Adnan, A. F., Saat, N., Aziz, N., \& Mat Taha, R. (2013). Optimization of extraction parameters by using response surface methodology, purification, and identification of anthocyanin pigments in melastoma malabathricum fruit. The Scientific World Journal, 2013. https://doi.org/10.1155/2013/810547

Astani, A., \& Schnitzler, P. (2014). Antiviral activity of monoterpenes beta-pinene and limonene against herpes simplex virus in vitro. Iranian Journal of Microbiology, 6(3), 149-155.

Dosoky, N. S., Satyal, P., Barata, L. M., Da Silva, J. K. R., \& Setzer, W. N. (2019). Volatiles of black pepper fruits (Piper nigrum L.). Molecules, 24(23), 1-13. https://doi.org/10.3390/molecules24234244

Fidyt, K., Fiedorowicz, A., Strządała, L., \& Szumny, A. (2016). $\beta$-caryophyllene and $\beta$-caryophyllene 
oxide - natural compounds of anticancer and analgesic properties. Cancer medicine, 5(10), 30073017. https://doi.org/10.1002/cam4.816

Klauke, A. L., Racz, I., Pradier, B., Markert, A., Zimmer, A. M., Gertsch, J., \& Zimmer, A. (2014). The cannabinoid CB2 receptor-selective phytocannabinoid beta-caryophyllene exerts analgesic effects in mouse models of inflammatory and neuropathic pain. European Neuropsychopharmacology, 24(4), 608-620. https://doi.org/10.1016/j.euroneuro.2013.10.008

Kusuma, H. S., \& Mahfud, M. (2015). Preliminary study: Kinetics of oil extraction from sandalwood by microwave-assisted hydrodistillation. ASEAN Journal of Chemical Engineering, 15(2), 62-69. https://doi.org/10.22146/ajche.49687

Lee, J. G., Kim, D. W., Shin, Y., \& Kim, Y. J. (2020). Comparative study of the bioactive compounds, flavours and minerals present in black pepper before and after removing the outer skin. $L w t$, 125(January), 109356. https://doi.org/10.1016/j.lwt.2020.109356

Mahdian, F., Mahboubi, M., Rahimi, E., \& Shad, M. M. (2017). Chemical composition, antimicrobial and antioxidant activities of Echinophora platyloba essential oil. Infectio, 21(3), 176-181. https://doi.org/10.22354/in.v21i3.675

Pawignya, H., Kusworo, T. D., \& Pramudono, B. (2019). Optimization for Production Tert-Butyl Glycoside Nonionic Surfactant Using Response Surface Methodology. Journal of Physics: Conference Series, 1295(1). https://doi.org/10.1088/1742-6596/1295/1/012003

Rmili, R., Ramdani, M., Ghazi, Z., Saidi, N., \& El Mahi, B. (2014). Composition comparison of essential oils extracted by hydrodistillation and microwave-assisted hydrodistillation from Piper nigrum L. Journal of Materials and Environmental Science, 5(5), 1360-1367.

Tran, T. H., Ha, L. K., Nguyen, D. C., Dao, T. P., Nhan, L. T. H., Nguyen, D. H., Nguyen, T. D., Vo, D. V. N., Tran, Q. T., \& Bach, L. G. (2019). The study on extraction process and analysis of components in essential oils of black pepper (Piper nigrum L.) seeds harvested in Gia Lai Province, Vietnam. Processes, 7(2). https://doi.org/10.3390/pr7020056 
